\title{
GST in India: A Big Leap in the Indirect Taxation System
}

\author{
Dr. R. Vasanthagopal
}

\begin{abstract}
The replacement of the Central excise duty of the government of India by Central Value Added Tax (CENVAT) and sales tax system of the State governments by the VAT marked a major mile stone in the reform process of indirect taxes in India. It addressed the cascading effect under the erstwhile system by giving set-off for tax paid on inputs as well as tax paid on previous purchases and resulted in a major simplification of the rate structure and broadening of the tax base. But both the CENVAT and the State VAT have certain incompleteness. Though a number of initiatives by the various machineries at the Centre, the present taxation regime is marked as cumbersome, complicated and unfriendly. It is in this perspective, the Central government has entrusted Dr.Vijay Kelkar, Chairman of 13th Finance Commission to suggest a rational, scientific and modern but unified system of taxation in tune with developed nations form the base behind the introduction of Goods and Service Tax (GST) in India. Although there are many hurdles to be crossed before the implementation of GST the Central government reiterated its commitment towards the adoption of a 'flawless' GST for the survival of the India's economy in the face of increasing international competition consequent to globalization and liberalisation. Despite the various impediments to the proposed transition, until the time GST is implemented, it would be worthwhile to assess its positive impacts on the various development areas viz. agriculture, manufacturing industry, MSME, housing, poverty reduction, employment, price level, EXIM trade, GDP, government revenue, etc. and this aspect is the subject matter of this paper.
\end{abstract}

Index Terms-Value Added Tax, Central Value Added Tax, Flaw less Goods and Services Tax, Gross domestic Product, Economic Change.

\section{INTRODUCTION}

The replacement of the Central excise duty of the government of India by the Central Value Added Tax (hereafter referred to as 'CENVAT') and sales tax system of the State governments by the VAT marked a major mile stone in the reform process of indirect taxes in India. It addressed the cascading effect under the erstwhile system by giving set-off for tax paid on inputs as well as tax paid on previous purchases and resulted in a major simplification of

the rate structure and broadening of the tax base. But both the CENVAT and the State VAT have certain incompleteness. The CENVAT has yet not been extended to include chain of value addition in the distributive trade below the stage of production. Again, several Central taxes viz. additional excise and customs duties, surcharge etc. also have

Manuscript received February 12, 2011.

Vasanthagopal is an Associate Professor with the P.G and Research Department of Commerce, The Cochin College, Kochi-682002, Kerala, India (phone: +919895018010; e-mail: vasanthagopalr@gmail.com) not been subsumed in the CENVAT, and thus keep the benefits of comprehensive input tax and service tax set-off out of the reach of producers/traders. Likewise, in the State VAT system, the cascading effect of CENVAT load on the goods has remained unrelieved. Hitherto, several taxes in the States viz. entertainment tax, luxury tax etc. have not been subsumed in the VAT. Thus, even after a number of initiatives by the various machineries at the Centre the present taxation regime is marked as cumbersome, complicated and unfriendly. It is in this perspective that the Central government has entrusted Dr.Vijay Kelkar, Chairman of 13th Finance Commission to suggest a rational, scientific, simplified and modern but unified system of taxation in tune with developed nations form the base behind the introduction of Goods and Service Tax (here after referred to as 'GST') in India.

GST is a broad based, single, comprehensive tax levied on goods and services at each point of sale of goods or provision of service, in which, the seller or service provider may claim the input credit of tax which he has paid while purchasing the goods or availing the service; the final consumer will thus bear only the GST charged by the last dealer in the supply chain. With the introduction of GST at the State level, the additional burden of CENVAT and services tax would be comprehensively removed and major Central and State taxes will get subsumed into GST which will reduce the multiplicity of taxes. Thus it marks a major improvement over the previous system of VAT. Again, the transparent and complete chain of set-offs, GST will help-widening the coverage of tax base and improve tax compliance. This may lead to higher revenue which further results in lowering of tax burden. Although there are many hurdles to be crossed before the implementation of GST like consensus over rates, constitutional amendment, compensation mechanism for States losing out on revenue, varying models, dispute resolution etc. the Central government has reiterated its commitment towards the adoption of a 'flawless' GST for the survival of the India's economy in the face of increasing international competition consequent to globalization and liberalisation. Despite the various impediments to the proposed transition, until the time GST is implemented, it would be worthwhile to assess its positive impacts on the various development areas in India. This aspect is the subject matter of this paper.

\section{RESUlts AND Discussion}

\section{A. GST and Agriculture}

Through a comprehensive and wider coverage of input and service taxes set-off, subsuming of several Central and State taxes in the GST and phasing out of CST, it is expected that 
the GST could increase the prices of agricultural produce between 0.61 and 1.18 per cent and this would be a boon to millions of farmers in India (Thirteenth Finance Commission, 2009).

\section{B. GST and Manufacturing Industry}

The incidence of the present multistage taxation increases the manufacturing cost of most of the production units in India. But a flawless GST can help this sector to reduce their cost to the extent of almost 50 per cent. This will help them to compete with their counterparts in the west. "Even a two per cent reduction in production cost will increase profits by over 20 per cent, giving headroom for reducing prices and benefitting end-users"(Kelkar,Vijay,2009).It is estimated that the implementation of GST would reduce the overall prices of all manufacturing sectors between 1.22 and 2.53 per cent (Thirteenth Finance Commission, 2009).

\section{GST and MSME}

The existing threshold of goods under State VAT is Rs. 5 lakh for a majority of bigger States and a lower threshold for North Eastern States and Special Category States. But as per the proposed GST enterprises above the turnover threshold Rs. 10 lakh both for goods and services will have to be registered. Again, keeping in view the interest of micro, small and medium enterprises and to avoid dual control, the States consider that the threshold for Central GST for goods may be kept at Rs. 1.5 crore and the threshold for services should also be appropriately high (Empowered Committee of Finance Ministers, 2009). This increase in threshold will adequately protect the interests of small traders and industries.

\section{GST and Housing}

At present, the value of a constructed property form part of stamp duty on land and other indirect taxes on inputs. On registration of the property, stamp duty is payable on the entire cost including the embedded taxes. There is no mechanism for complete off-set of these taxes. This results in an increase in the overall cost of the property. The GST provides for including within its scope the transactions in real estate. Therefore, for a registered real estate builder, all taxes on inputs (including that on land) will be off-set against the tax payable on the constructed property. This will reduce cost of housing to the extent of embedded taxes and hence will benefit the poor.

\section{E. GST and Poverty Reduction}

At present, primary food articles like rice and wheat are liable to tax by many States either by way of purchase tax or sales tax at a lower rate. But under the GST, all food items covered under the public distribution system including rice and wheat are proposed to be exempted. As a result primary food articles like rice and wheat would be exempted from GST. Since expenditure on food constitutes a large proportion of the total consumption expenditure of the poor, the GST is designed as a poverty reduction initiative. Like food, basic health and education services are also intended to be fully exempted. In any case, as at present, these services will continue to be exempted from tax and therefore no additional burden will arise on account of the switchover to GST (Thirteenth Finance Commission (2009).

\section{F. GST and Employment}

It is seen that the implementation of GST would result in increased income and output in various sectors of the economy. On account of this increase in higher growth, there will be large scale employment opportunities in various areas like the skilled, semi skilled and unskilled categories.

\section{G. GST and Factors of Production}

It is also estimated that the implementation of a flawless GST in India would result in efficient allocation of factors of production thus leading to gain in factors of production, i.e. land, labour and capital. The gains in real returns to land range between 0.42 and 0.82 per cent. Wage rate gains vary between 0.68 and 1.33 per cent. The real returns to capital would gain in the range of 0.37 and 0.74 percent (Thirteenth Finance Commission, 2009)

\section{H. GST and Price Level}

Though there is an allegation that GST is a regressive tax as it minimizes the number of tax rates to even a single (dual) rate, the subsuming of major Central and State taxes in GST, continuous chain of set-off of input goods and services and phasing out of CST the commitment of taxes on goods would come down under GST. It is anticipated that, other things remaining the same, this would encourage manufacturers and distributors to reduce the prices of their produce and ultimately benefit the consumers. Hence, a 'flawless' GST would be viewed as pro-poor and not regressive.

\section{GST and Exim Trade}

At present export of taxes to other countries is sought to be eliminated through the mechanisms of duty draw back on the basis of estimated incidence of embedded taxes. By considering its weakness the GST requires that exports from the taxing jurisdiction would be tax free and imports into the jurisdiction would be taxed at the same rate as products produced and consumed within the jurisdiction. Consequently, both export-oriented industries and import-substituting industries would become internationally more competitive. As a result, while exports can be expected to register an increase, imports are likely to decrease. The gains in exports are expected to vary between 3.2 and 6.3 per cent and imports are expected to gain somewhere between 2.4 and 4.7 per cent (Thirteenth Finance Commission, 2009).

\section{J. GST and GDP}

The implementation of a 'flawless' GST across goods and services is expected to induce India's Gross Domestic Product (here after referred to as 'GDP') somewhere within a range of 0.9 to 1.7 per cent. Again, these additional gains in GDP would be earned during ever year over and above the growth in GDP which would have been achieved otherwise.

\section{K. GST and Government Revenue}

Since all goods and services would be under the purview of GST, it is expected that the number of exemptions would reduce very much. Again, the tendency of tax evasion by producers and distributors will be low as to the single (or dual) and low rate of tax proposed under GST. Further, increased GDP, indirect positive impact on direct tax collections, gain for the government on account of reduction in the price level 
of a large number of goods and services consumed by the government as a result GST etc. a flawless GST would trigger an increase in the government revenue.

\section{CONCLUSION}

To conclude, though the positive impacts referred above are dependent on a neutral and rational design of the GST, balancing the conflicting interests of various stakeholders, full political commitment for a fundamental tax reform with a constitutional amendment, the switchover to a 'flawless' GST would be a big leap in the indirect taxation system and also give a new impetus to India's economic change. It is also noted that, buoyed by the success of GST, more than 140 countries have introduced GST in some form to other and is fast becoming the preferred form of indirect tax in the Asia Pacific region.

\section{REFERENCES}

[1] Empowered Committee of Finance Ministers (2009). First Discussion Paper on Goods and Services Tax in India, The Empowered Committee of State Finance Ministers, New Delhi.
[2] Empowered Committee of State Finance Ministers (2008). A Model and Roadmap for Goods and Services Tax in India, New Delhi.

[3] John P.V (2010). Reforms in Sales Tax Structure: A Study with Special Reference to VAT in Kerala, Unpublished PhD Thesis, Mahatma Gandhi University, Kottayam.

[4] Kelkar,Vijay (2009). GST Reduces Manufacturing Cost and Increases Employment, Times of India, October 13.

[5] Kelkar,Vijay, et al (2004). Report on Implementation of the Fiscal Responsibility and Budget Management Act, 2003. Ministry of Finance, Government of India, New Delhi.

[6] Poddar, Satya and Amaresh Bagchi (2007), Revenue-neutral rate for GST, The Economic Times, November 15.

[7] Rajkumar S.Adukir (2009). A Study on Proposed Goods and Services Tax (GST) Frame work in India, Paper presented at the National Tax Association, Annual conference of Taxation, New Delhi, Nov.10-11.

[8] Thirteenth Finance Commission (2009). Report of the Task Force on Goods and Services Tax, New Delhi.

Dr. R.Vasanthagopal. lace: Kerala, India. Date of birth:25/5/1969. Educational qualification: M.Com-Finance-1991, studied at The Departmen of Commerce, University of Kerala. M.Phil-Commerce. PhD-Industrial relations-1998.Now working as Associate Professor, P.G. and Research Department of Commerce, The Cochin College, Kochi, Kerala, India. Dr. R.Vasanthagopal has produced $6 \mathrm{PhDs}$ and Published 12 research articles in journals. 